\title{
Uji Daya Hambat Filtrat Zat Metabolit Lactobacillus plantarum Terhadap Pertumbuhan Shigella dysenteriae Secara In Vitro
}

\author{
RIZKI PUTRI ANDINI RAHMAH ${ }^{1}$, MEISKHA BAHAR ${ }^{2}$, YANTI HARJONO ${ }^{3}$ \\ ${ }^{1}$ Program Studi Sarjana Kedokteran, Fakultas Kedokteran UPN Veteran \\ Jl. RS Fatmawati, Pondok Labu, Jakarta Selatan 12450 \\ email: rparahmah@gmail.com \\ ${ }^{2}$ Departemen Mikrobiologi, Fakultas Kedokteran UPN Veteran \\ Jl. RS Fatmawati, Pondok Labu, Jakarta Selatan 12450 \\ ${ }^{3}$ Departemen Ilmu Kesehatan Masyarakat, Fakultas Kedokteran UPN Veteran \\ Jl. RS Fatmawati, Pondok Labu, Jakarta Selatan 12450
}

\begin{abstract}
Shigella dysenteriae is pathogenic bacteria causes dysentery diarrhea, a diarrhea with mucus and blood in the feces. Currently, drugs or foods containing Lactobacillus have been circulated in the markets and used by people. This research aims to know the in vitro inhibition test of $L$. plantarum metabolite substances filtrate against growth of $S$. dysenteriae. This research used experimental design with $L$. plantarum metabolite substances filtrate as the samples. Antibacterial test method which was used was the cup-plate technique by looking at clear zone of bacteria's growth around cup-plate and used Mueller Hinton Agar media. The results showed clear zones on filtrate with concentrations $25 \%, 50 \%, 75 \%$, and $100 \%$ with average inhibition zones $0,284 \mathrm{~cm}$; $0,332 \mathrm{~cm} ; 0,406 \mathrm{~cm}$; and 0,619 cm. Kruskal-Wallis test results indicated there were significant differences of each filtrate concentration against $S$. dysenteriae $(\mathrm{p}<0,05)$. Post Hoc test showed no significant difference between concentrations $25 \%$ and $50 \%(\mathrm{p}>0,05)$. This suggested lactic acid, acetic acid, and bacteriosin presented in L. plantarum metabolite have antibacterial characteristic.
\end{abstract}

Keywords: antibacterial, Lactobacillus plantarum, Shigella dysenteriae

\section{INTISARI}

Shigella dysenteriae merupakan bakteri patogen penyebab diare disentri, yaitu kondisi diare disertai lendir dan darah dalam feses. Saat ini, sediaan obat atau makanan yang mengandung Lactobacillus telah beredar di pasaran dan dimanfaatkan oleh masyarakat. Tujuan penelitian ini adalah untuk mengetahui daya hambat filtrat zat metabolit L. plantarum terhadap pertumbuhan $S$. dysenteriae secara in vitro. Penelitian ini menggunakan desain eksperimental dengan sampel filtrat zat metabolit L. plantarum. Metode uji antibakteri yang digunakan adalah metode sumuran dengan melihat zona hambat pertumbuhan bakteri di sekitar sumuran. Hasil penelitian ini memperlihatkan adanya zona bening pada konsentrasi filtrat $25 \%, 50 \%, 75 \%$, dan $100 \%$ dari pertumbuhan $S$. dysenteriae dengan rata-rata zona hambat $2,84 \mathrm{~mm} ; 3,32 \mathrm{~mm} ; 4,06 \mathrm{~mm}$; dan $6,19 \mathrm{~mm}$. Hasil uji Kruskal-Wallis menunjukkan perbedaan signifikan masing-masing konsentrasi filtrat terhadap $S$. dysenteriae $(\mathrm{p}<0,05)$. Pada uji Post Hoc, kelompok konsentrasi $25 \%$ dan $50 \%$ menunjukkan tidak terdapat perbedaan signifikan ( $>00,05)$. Penelitian ini menunjukkan bahwa asam laktat, asam asetat, dan bakteriosin yang terdapat pada metabolit L. plantarum dapat bersifat sebagai antibakteri.

Kata kunci: antibakteri, Lactobacillus plantarum, Shigella dysenteriae

\section{PENDAHULUAN}

Diare merupakan masalah kesehatan dunia karena morbiditas (angka kesakitan) dan mortalitasnya (angka kematian) yang tinggi serta merupakan salah satu dari tiga penyakit utama selain pneumonia dan malaria, yang menyebabkan kematian pada anak-anak (WHO, 2012). Diare adalah suatu kondisi buang air besar dengan konsistensi lembek atau cair, bahkan dapat berupa air 
saja dengan frekuensi yang lebih sering (biasanya tiga kali atau lebih) dalam satu hari (Depkes RI, 2011).

Di Indonesia, penyakit diare masih merupakan masalah kesehatan utama karena morbiditas dan mortalitasnya yang tinggi. Survei morbiditas yang dilakukan oleh Subdit Diare, Departemen Kesehatan dari tahun 2003-2010 terlihat kecenderungan insiden naik dari 301/1000 penduduk pada tahun 2003 menjadi 411/1000 penduduk tahun 2010 (Balitbang Kemenkes RI, 2013). Penyebab diare yang terpenting dan sering terjadi di negara berkembang adalah Shigella, khususnya $S$. dysenteriae dan $S$. boydi yang menyebabkan diare disentri (Centers for Disease Control and Prevention, 2016). Disentri merupakan kumpulan gejala penyakit seperti diare berdarah, lendir dalam tinja, nyeri saat mengeluarkan tinja, dan dapat juga demam (IDAI, 2013). Infeksi Shigella sebesar $69 \%$ pada anak berusia kurang dari 5 tahun (NCBI, 2008). Disentri berat umumnya disebabkan oleh $S$. dysenteriae (Standards Unit, Microbiology Services, PHE 2015).

Menurut Kaboosi (2011), probiotik ialah suatu mikroorganisme hidup yang apabila diberikan dalam jumlah adekuat akan bermanfaat bagi kesehatan host. Kelompok probiotik yang terdiri dari Lactobacillus dan Bifidobacteria atau Saccharomyces boulardii, apabila mengalami peningkatan jumlah di saluran cerna akan memiliki efek yang positif karena berkompetisi untuk nutrisi dan reseptor saluran cerna.

Sediaan obat atau makanan yang mengandung probiotik telah beredar di pasaran dan dimanfaatkan oleh masyarakat untuk berbagai tujuan, misalnya anti diare (Allen, 2011). L. plantarum mempunyai kemampuan untuk menghambat mikroorganisme patogen dengan daerah penghambatan terbesar dibandingkan dengan bakteri asam laktat lainnya (Rahayuningtyas, 2011). Menurut Lourens-Hattingh dan Viljoen (2001), Lactobacillus sp. menghasilkan beberapa metabolit antara lain asam laktat, asam asetat, dan bakteriosin yang mampu menghambat pertumbuhan dan/atau membunuh bakteri patogen.
Mekanisme lain yang menyebabkan probiotik mampu melawan mikroba patogen adalah antagonis kompetitif melalui kompetisi adesi pada sel epitel, penggunaan nutrisi dan meningkatkan sistem imun tubuh inang (Nelintong, 2015). Bakteri probiotik mempunyai afinitas pengikatan yang tinggi terhadap membran sel epitel mukosa dan dapat bertindak sebagai pembawa antigen sehingga dapat mengaktivasi makrofag untuk merangsang respon imun dengan diproduksinya immunoglobulin A (Dewi dan Anggraini, 2015).

Menurut penelitian Poppi et al. (2015), L. plantarum menghasilkan asam laktat dan asam asetat yang dapat menghambat pertumbuhan E. coli. Asam laktat yang dihasilkan L. plantarum mampu menurunkan $\mathrm{pH}$ menjadi rendah sehingga bakteri patogen akan sulit bertahan hidup (Tambekar and Bhutada, 2010). L. plantarum juga menghasilkan bakteriosin yang dapat menghambat pertumbuhan bakteri patogen (Yulinery dan Nurhidayat, 2015). Bakteriosin menyebabkan kebocoran sel yang mengakibatkan kematian sel bakteri (Fauziah dkk., 2014)

Penelitian ini bertujuan untuk mengetahui adanya daya hambat filtrat zat metabolit $L$. plantarum terhadap pertumbuhan $S$. dysenteriae, serta mengetahui konsentrasi filtrat zat metabolit $L$. plantarum yang paling efektif dalam menghambat pertumbuhan $S$. dysenteriae.

\section{METODE}

Sampel Penelitian. Penelitian ini dilakukan di Laboratorium Mikrobiologi Fakultas Kedokteran Universitas Pembangunan Nasional "Veteran" Jakarta. Sampel pada penelitian ini adalah $L$. plantarum $\mathrm{B} 122$. L. plantarum $\mathrm{B} 122$ selanjutnya diproses sehingga diperoleh filtrat zat metabolitnya. Sampel akan diberikan ke subjek penelitian yaitu bakteri $S$. dysenteriae yang diperoleh dari Departemen Mikrobiologi Fakultas Kedokteran Universitas Indonesia.

Penghitungan besar pengulangan dari tiap kelompok perlakuan ditentukan dengan menggunakan rumus Federer. Kelompok 
perlakuan berjumlah empat yaitu pemberian filtrat zat metabolit L. plantarum B122 konsentrasi 25\%, 50\%, 75\%, 100\% dan dua kelompok kontrol, yaitu satu kelompok kontrol positif berupa antibiotik dan satu kelompok kontrol negatif berupa akuades.

$$
\begin{aligned}
& \text { Rumus Federer: }(\mathrm{n}-1)(\mathrm{t}-1) \geq 15 \\
& \text { Perlakuan terhadap S.dysenteriae } \\
& (\mathrm{n}-1)(\mathrm{t}-1) \geq 15 \rightarrow(\mathrm{n}-1)(6-1) \geq 15 \\
& \rightarrow(\mathrm{n}-1)(5) \geq 15 \rightarrow 5 \mathrm{n} \geq 15+5 \\
& \rightarrow \mathrm{n} \geq 20 / 5 \rightarrow \mathrm{n} \geq 4
\end{aligned}
$$

Keterangan: $\mathrm{n}=$ jumlah ulangan ; $\mathrm{t}=$ jumlah kelompok perlakuan dan kelompok kontrol (6)

Berdasarkan perhitungan diatas, maka tiap kelompok percobaan dilakukan pengulangan sebanyak empat kali.

Pembuatan Starter L. plantarum. $L$. plantarum B122 dikultur dalam agar miring dan media the Man Rogosa Sharpe (MRS) broth, pada suhu $37^{\circ} \mathrm{C}$, selama 24 jam. Selanjutnya kultur L. plantarum B122 sebanyak $2 \%$ dipindahkan ke dalam $50 \mathrm{~mL}$ MRS broth, diinkubasi pada suhu $37^{\circ} \mathrm{C}$, selama 24 jam. Kemudian L. plantarum B122 sebanyak $2 \%$ dikultur dalam $500 \mathrm{~mL}$ MRS broth, pada suhu $37^{\circ} \mathrm{C}$, selama 18 jam (Wardoyo, 2008 dan Poppi et al., 2015).

Pembuatan Filtrat Zat Metabolit $L$. plantarum. Filtrat zat metabolit L. plantarum B122 diperoleh dengan cara sentrifugasi $L$. plantarum B122 yang telah teraktivasi dalam MRS broth dengan kecepatan $8.000 \mathrm{rpm}$ selama 15 menit untuk memisahkan sel dengan filtratnya (supernatan). Filtrat yang diperoleh disterilkan menggunakan filter milipore 0,2 $\mu \mathrm{m}$ (Poppi et al., 2015 dan Fauziah dkk., 2014).
Persiapan Bakteri Uji. Pembuatan suspensi bakteri $S$. dysenteriae dengan larutan $\mathrm{NaCl} 0,9 \%$ hingga terbentuk kekeruhan yang mencapai standar 0,5 McFarland. Suspensi bakteri $S$. dysenteriae $1 \mathrm{ml}$ dimasukkan ke dalam media Mueller Hinton Agar (MHA) 20 ml, kemudian dihomogenkan membentuk lapisan yang rata sebagai seed layer dan dibiarkan setengah padat.

Uji Aktivitas Antibakteri. Filtrat yang diperoleh selanjutnya dilakukan uji HPLC untuk mengetahui kadar asam laktat dan asam asetat yang didapatkan. Filtrat dibuat dalam konsentrasi $25 \%, 50 \%, 75 \%, 100 \%$ untuk selanjutnya dilakukan uji aktivitas antibakteri dengan menggunakan metode sumuran atau difusi plat silinder. Larutan filtrat uji dan larutan kontrol dimasukkan ke dalam sumuran atau lempeng silinder kemudian diinkubasi pada suhu $37^{\circ} \mathrm{C}$ selama 24 jam. Seluruh cawan yang telah diinkubasi diamati untuk melihat zona hambat yang terbentuk di sekeliling sumuran. Pengukuran menggunakan jangka sorong digital dengan mengukur dari tepi ke tepi melewati sumuran, kemudian dilakukan percobaan sebanyak 4 kali.

Analisis Data. Analisis data hasil penelitian ini dilakukan dengan uji KruskalWallis dan kemudian dilanjutkan dengan uji Post Hoc (Mann-Whitney) untuk mengetahui perbedaan setiap kelompok (Dahlan, 2011).

\section{HASIL}

Hasil penelitian zona hambat filtrat zat metabolit L. plantarum B122 terhadap $S$. dysenteriae dipaparkan dalam Tabel 1 berikut.

Tabel 1. Rata-Rata Zona Hambat Filtrat Zat Metabolit L. plantarum B122

\begin{tabular}{cc}
\hline Konsentrasi & Rata-rata Diameter Zona Hambat S. dysenteriae (cm) \\
\hline $25 \%$ & 0,284 \\
\hline $50 \%$ & 0,332 \\
\hline $75 \%$ & 0,406 \\
\hline $100 \%$ & 0,619 \\
\hline Kontrol Negatif & 0 \\
\hline Kontrol Positif & 3,075 \\
\hline
\end{tabular}

Tabel 1 menunjukkan bahwa filtrat zat metabolit L. plantarum B122 pada konsentrasi $25 \%, 50 \%, 75 \%$, dan $100 \%$ dapat menghambat pertumbuhan $S$. dysenteriae. 
Zona hambat terbesar dihasilkan oleh filtrat dengan konsentrasi $100 \%$ yaitu rata-rata sebesar 0,619 cm, diikuti dengan konsentrasi $75 \%$ sebesar $0,406 \mathrm{~cm}$, konsentrasi $50 \%$ sebesar $0,332 \mathrm{~cm}$, dan yang terkecil adalah konsentrasi $25 \%$ sebesar $0,284 \mathrm{~cm}$.
Terdapat banyak zat metabolit yang terkandung di dalam filtrat, termasuk yang diuji pada penelitian ini adalah kadar asam laktat dan asam asetat seperti yang terdapat pada tabel 2 berikut.

Tabel 2. Kadar Asam Organik yang dihasilkan L. plantarum B122

\begin{tabular}{ccc}
\hline Bakteri & \multicolumn{2}{c}{ Produksi asam organik dalam MRS broth } \\
\cline { 2 - 3 } & Asam Laktat $(\mathrm{g} / \mathrm{L})$ & Asam Asetat $(\mathrm{g} / \mathrm{L})$ \\
\hline L. plantarum $\mathrm{B} 122$ & 28,01 & 9,72 \\
\hline
\end{tabular}

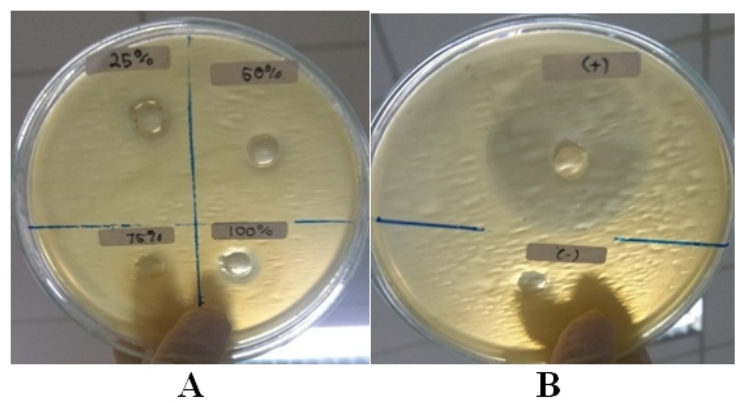

Gambar 1. Zona hambat S.dysenteriae pada media MHA. A. Penghambatan pertumbuhan S.dysenteriae oleh filtrat zat metabolit L.plantarum B122. B. Kontrol positif (antibiotik) dan kontrol negatif (akuades).

Gambar 1 menunjukkan tampilan zona hambat berupa zona bening di sekitar sumuran yang berisi filtrat konsentrasi $25 \%$, $50 \%, 75 \%, 100 \%$.

\section{PEMBAHASAN}

Hasil penelitian ini menunjukkan peningkatan besar zona hambat yang terbentuk dimulai dari konsentrasi 25\% sampai $100 \%$. Menurut penelitian Rastina dkk. (2015), kemampuan suatu antimikroba dalam menghambat mikroorganisme tergantung pada konsentrasi bahan antimikroba dan jenis bahan antimikroba yang dihasilkan. Semakin besar konsentrasi suatu antimikroba, maka semakin besar zona bening yang terbentuk. Hal ini disebabkan karena semakin tinggi konsentrasi bahan antimikroba, maka semakin banyak zat aktif yang terkandung di dalamnya sehingga efektivitas dalam menghambat bakteri akan semakin meningkat dan menghasilkan zona bening yang lebih luas. Sebaliknya, pada konsentrasi yang rendah maka zat antimikroba yang terdapat di dalam suatu bahan antimikroba akan semakin sedikit, sehingga aktivitasnya akan semakin berkurang (Pratiwi, 2016). Menurut Lorain (2005) semakin besar konsentrasi antimikroba, maka semakin cepat terjadi difusi, sehingga daya antibakteri akan semakin besar dan diameter zona hambat yang dihasilkan semakin luas.

Davis \& Stout (2009) membagi kekuatan daya antibakteri menjadi empat kategori, yaitu menghambat lemah $(<5 \mathrm{~mm})$, sedang $(5-10 \mathrm{~mm})$, kuat $(10-20 \mathrm{~mm})$, dan sangat kuat $(>20 \mathrm{~mm})$. Pada penelitian ini, daya hambat filtrat L. plantarum B122 pada konsentrasi $25 \%, 50 \%, 75 \%$ termasuk ke dalam kategori lemah, sedangkan daya hambat filtrat pada konsentrasi $100 \%$ termasuk ke dalam kategori sedang.

Berdasarkan uji statistik Kruskal-Wallis, didapatkan adanya perbedaan bermakna daya hambat filtrat dengan konsentrasi yang berbeda terhadap pertumbuhan $S$. dysenteriae. Pada uji Post Hoc (Mann-Whitney), didapatkan bahwa pada kelompok konsentrasi $25 \%$ dan $50 \%$ tidak terdapat perbedaan 
bermakna. Hal ini disebabkan karena konsentrasi filtrat yang efektif dalam menghambat bakteri patogen (Bacillus cereus, Staphylococcus aureus, Salmonella paratiphy, dan E. coli) yaitu pada konsentrasi $50 \%$ sampai $100 \%$ (Sulistijowati dan Mile, 2016).

Penelitian ini sesuai dengan penelitian Poppi et al. (2015) yang menguji efektivitas antibakteri filtrat $L$. plantarum terhadap $E$. coli, didapatkan hasil bahwa asam laktat dan asam asetat yang terdapat pada filtrat dapat menghambat pertumbuhan $E$. coli dengan diameter zona hambat sebesar $18 \mathrm{~mm}$. Pada penelitian Maunatin dan Khanifa (2012) dengan menggunakan metode sumuran, $L$. plantarum dapat menghambat $S$. aureus dan $S$. typhi dengan diameter zona hambat masing-masing sebesar $13,3 \mathrm{~mm}$ dan $9,3 \mathrm{~mm}$. Penelitian ini juga sesuai dengan penelitian Prema (2013) yang menguji efektivitas filtrat bakteriosin $L$. plantarum terhadap $S$. dysenteriae, didapatkan bahwa filtrat bakteriosin dapat menghambat pertumbuhan S. dysenteriae.

Aktivitas daya hambat filtrat zat metabolit L. plantarum B122 terhadap $S$. dysenteriae disebabkan karena adanya senyawa antibakteri seperti asam laktat dan asam asetat yang terdeteksi pada HPLC dengan konsentrasi asam laktat sebesar 28,01 $\mathrm{g} / \mathrm{L}$ dan asam asetat sebesar 9,72g/L di dalam $100 \mathrm{ml}$ filtrat. Kadar asam laktat dan asam asetat yang dihasilkan L. plantarum B122 pada penelitian ini lebih besar dari $L$. plantarum isolat 22c yang hanya menghasilkan asam laktat dan asam asetat sebesar $18,5 \mathrm{~g} / \mathrm{L}$ dan $4,2 \mathrm{~g} / \mathrm{L}$ (Poppi et al., 2015). Hal ini karena metabolit yang dihasilkan oleh bakteri asam laktat dipengaruhi oleh kondisi fermentasi dan strain bakteri asam laktat tersebut (Yuliani, 2005).

Produksi asam laktat dan asam asetat oleh L. plantarum B122 dalam filtrat dapat menyebabkan $\mathrm{pH}$ media menjadi rendah $(<4,5)$ (Nurhajati et al., 2012). Asam laktat mudah terdisosiasi menghasilkan $\mathrm{H}^{+}$dan $\mathrm{CH}_{3} \mathrm{CHOHCOO}^{-}$, sedangkan asam asetat dapat terdisosiasi menghasilkan $\mathrm{H}^{+}$dan $\mathrm{CH}_{3} \mathrm{COO}^{-}$(Syachroni, 2014). Adanya ion $\mathrm{H}^{+}$ menyebabkan penurunan nilai $\mathrm{pH}$ yang dapat menghambat bakteri patogen, dimana $S$. dysenteriae memiliki $\mathrm{pH}$ optimum antara 6,4 sampai 7,8 untuk pertumbuhannya (Syahrurachman, 2010). Proton (ion $\mathrm{H}^{+}$) yang dihasilkan oleh proses disosiasi asam laktat dan asam asetat akan masuk ke dalam sel bakteri patogen karena adanya gradien proton. Selanjutnya bakteri akan berusaha untuk mempertahankan $\mathrm{pH}$ alkali dalam sel dengan mengeluarkan proton tersebut dari dalam sel. Proses pengeluaran proton ini membutuhkan energi yang tinggi, sehingga mengakibatkan bakteri mati karena kehabisan energi. Beberapa molekul asam laktat dan asam asetat yang tidak terdisosiasi (netral) di luar sel juga dapat berdifusi melewati membran sel karena bersifat larut dalam lipid. Setelah memasuki sel, asam akan terdisosiasi pada sitoplasma bakteri (Viogenta, 2010 dan Fauziah dkk., 2014).

Bakteriosin yang terdapat dalam filtrat zat metabolit L. plantarum B122 memiliki aktivitas antibakteri. Mekanisme bakteriosin adalah dengan merusak permeabilitas membran bakteri dan menghilangkan proton motive force (PMF) sehingga menghambat produksi energi dan sintesis protein bakteri. Bakteriosin menyebabkan kebocoran sel bakteri sehingga mengubah gradien potensial membran dan pelepasan molekul intraseluler serta masuknya substansi ekstraseluler. Proses tersebut akan menyebabkan kematian sel bakteri patogen (Usmiati dkk., 2009). Aktivitas antibakteri bakteriosin membutuhkan lipid membran sitoplasma yang bermuatan negatif sebagai reseptor utama dalam proses pembentukan pori. Bakteriosin bermuatan positif yang bersifat hidrofobik akan berikatan dengan gugus fosfat bermuatan negatif pada membran sel target. Selanjutnya bagian hidrofobik bakteriosin masuk ke dalam membran membentuk pori (Viogenta, 2010).

Aktivitas antibakteri asam laktat, asam asetat, dan bakteriosin terhadap bakteri patogen dipengaruhi oleh struktur dinding sel bakteri patogen. Bakteri Gram negatif memiliki lapisan peptidoglikan yang lebih tipis daripada bakteri Gram positif. Bakteri 
Gram positif memiliki lapisan peptidoglikan yang tebal yaitu 20-80 nm, sedangkan lapisan peptidoglikan bakteri Gram negatif hanya setebal 2-7 nm. Berat peptidoglikan bakteri Gram negatif hanya sebesar 5-10\% dari berat dinding sel. Hal ini menyebabkan bakteri Gram negatif lebih sensitif terhadap zat antibakteri. Dinding sel bakteri Gram negatif mengandung lipid yang lebih banyak daripada bakteri Gram positif. Membran luar sel tersusun atas lipoprotein $30 \%$, fosfolipid 20$25 \%$, protein $40-45 \%$.Lipid ini menyebabkan bakteri lebih sensitif terhadap bakteriosin dan asam organik pada filtrat, dimana lipid merupakan reseptor utama bakteriosin, serta asam organik yang tidak terdisosiasi bersifat hidrofobik sehingga memudahkan zat antibakteri pada filtrat tersebut untuk masuk ke dalam sel bakteri (Prescott et al., 2002).

\section{KESIMPULAN}

Berdasarkan penelitian yang telah dilakukan, maka dapat disimpulkan sebagai berikut:

a. Filtrat zat metabolit L. plantarum B122 pada konsentrasi $25 \%, 50 \%, 75 \%$, dan $100 \%$ memiliki daya hambat terhadap pertumbuhan $S$. dysenteriae secara in vitro.

b. Rata-rata luas zona hambat tertinggi terdapat pada kelompok perlakuan filtrat zat metabolit L. plantarum $\mathrm{B} 122$ konsentrasi $100 \% \quad(0,619 \quad \mathrm{~cm}) \quad$ dan terendah pada kelompok perlakuan filtrat zat metabolit L. plantarum B122 konsentrasi $25 \%(0,284 \mathrm{~cm})$.

\section{DAFTAR PUSTAKA}

Allen SJ. 2011. Probiotics for treating acute infectious diarrhea. Sao Paulo Medical Journal. vol. 129(3): 185.

Balitbang Kemenkes RI 2013. Riset Kesehatan Dasar; RISKESDAS. Jakarta: Balitbang Kemenkes RI.

Centers for Disease Control and Prevention. 2016. Shigella-Shigellosis. https://www.cdc.gov/shigella/generalinformation.html. Diakses 17 Januari 2017.
Dahlan MS. 2011.Statistik Untuk Kedokteran dan Kesehatan Edisi5. Jakarta: Salemba Medika. Hal 88.

Davis WW \& Stout TR. 2009. Disc Plate Method of Microbiological Antibiotic Assay. Applied and Enviromental Microbiology. vol. 22 (4): 666-670.

Depkes RI. 2011.Buku Saku Lintas Diare. Jakarta: Departement Kesehatan RI. hal 2.

Dewi SS, Anggraini H. 2015. Aktivitas Lactobacillus plantarum Isolat ASI terhadap Imunoglobulin (IgA, IgG) pada Tikus Wistar Model Sepsis. Seminar Prosiding Nasional. Semarang: University Research Coloqium Universitas Muhammadiyah. ISSN 24079189. hal 503-506.

Fauziah PN, Nurhajati J, Chrysanti. 2014. Daya Antibakteri Filtrat Asam Laktat dan Bakteriosin Lactobacillus bulgaricus KS1 dalam Menghambat Pertumbuhan Klebsiella pneumoniae Strain ATCC 70603, CT1538, dan S941. MKB. vol 47 (1): 35-41.

IDAI. 2013.2 Disentri. http://www.idai.or.id/artikel/seputarkesehatan-anak/disentri. Diakses 22 Agustus 2016.

Kaboosi H. 2011. Antibacterial Effects of Probiotics Isolated from Yoghurt Against Some Common Bacterial Pathogens. African Journal of Microbiology Research. vol 5 (25): 4363-4367.

Lorain V. 2005. Antibiotic in Laboratory Medicine. $5^{\text {th }}$ Edition. London: Williams and Wilkins Co. p 259.

Lourens-Hattingh A, Viljoen BC. 2001. Yoghurt as Probiotic Carrier Food. International Dairy Journal. vol 11(1): 1-17.

Maunatin A, Khanifa. 2012. Uji Potensi Probiotik Lactobacillus plantarum secara In Vitro. Jurnal Alchemi. vol 2 (1): 2634.

NCBI. 2008. Options for Treating Resistant Shigella Species Infections in Children. http://www.ncbi.nlm.nih.gov/. Diakses Januari 2017. 
Nelintong N. 2015.Aktivitas Antibakteri Susu Probiotik Lactobacilli Terhadap Bakteri Penyebab Diare (Escherichia coli, Salmonella typhimurium, Vibrio cholerae). Jurnal Farmasi dan Ilmu Kefarmasian Indonesia. vol. 2 (1): 25-30.

Nurhajati J, Sayuti, Chrysanti, Syachroni. 2012. An In-Vitro Model for Studying the Adhesion of Lactobacillus bulgaricus in Soyghurt and Enteropathogenic Escherichia coli (EPEC) on Hep-2 Cells. African Journal of Microbiology Research. vol. 6 (24): 5142-5146.

Pratiwi S. 2016. Uji Efektivitas Ekstrak Daun Cincau Hijau Rambat (Cyclea barbata Miers.) Sebagai Antibakteri Terhadap Bacillus cereus dan Shigella dysenteriae Secara In Vitro Dengan Metode Difusi. [Skripsi]. Jakarta: Universitas Pembangunan Nasional "Veteran".

Prema P. 2013. In Vitro Antagonistic Activity of a Probiotic Lactobacillus plantarum Against Water Borne Pathogens. International Journal of Pharmacy and Pharmaceutical Sciences. vol 5 (4): 175178.

Prescott LM, Horley JP, Klein DA. 2002. Microbiology. $5^{\text {th }}$ Edition. Boston: Mc Graw-Hill. p 55.

Poppi LB, Rivaldi JD, Coutinho TS, Ferreira ACS, Ferreira AJP, Mancilha IM. 2015. Effect of Lactobacillus sp. Isolates Supernatant on Escherichia coli O157:H7 Enhances the Role of Organic Acids Production as a Factor for Pathogen Control. Pesq Vet Bras. vol 35 (4): 353-359.

Rahayuningtyas N. 2011.Uji Aktivitas Antibakteri Isolat Lactobacillus plantarum dari Buah-Buahan Tropis dan Kaitannya dengan Ekspresi Gen Plantaricin. [Skripsi]. Bogor: Institut Pertanian Bogor.

Rastina, Sudarwanto M, Wientarsih I. 2015. Aktivitas Antibakteri Ekstrak Etanol Daun Kari (Murraya koenigii) Terhadap Staphylococcus aureus, Escherichia coli, dan Pseudomonas sp. Jurnal Kedokteran Hewan. vol 9 (2): 185-188.
Standards Unit, Microbiology Services, PHE. 2015. UK Standards for Microbiology Investigations: Identification of Shigella Species. Bacteriology-Identification. vol 20 (3): 1-22.

Sulistijowati R dan Mile L. 2016. Efektivitas Penghambatan Filtrat Asam Laktat Lactobacillus sp. Hasil Isolasi Dari Usus Ikan Bandeng (Chanos chanos) Terhadap Bakteri Patogen. Prosiding Seminar Nasional. 14 Juni 2016. Gorontalo: Universitas Negeri Gorontalo.

Syachroni. 2014. Pengaruh Kombinasi Starter Kultur L. plantarum dan L. acidophilus terhadap Karakteristik Mikrobiologis dan Kimiawi pada Minuman Fermentasi. [Skripsi]. Makassar: Universitas Hasanuddin.

Syahrurachman A. 2010. Buku Ajar Mikrobiologi Kedokteran. Tangerang: Binarupa Aksara Publisher. hal 198.

Tambekar DH, Bhutada SA. 2010. An Evaluation of Probiotic Potential of Lactobacillus sp. from Milk of Domestic Animals and Commercial Available Probiotic Preparations in Prevention of Enteric Bacterial Infections. Recent Research in Science and Technology. vol 2 (10): 82-88.

Usmiati S, Miskiyah, Rarah RAM. 2009. Pengaruh Penggunaan Bakteriosin dari Lactobacillus sp. Galur SCG 1223 Terhadap Kualitas Mikrobiologi Daging Sapi Segar. JITV. vol 14 (2): 150-166.

Viogenta P. 2010. Karakteristik Anti Bakteri Isolat Lactobacillus dari Tempoyak. [Skripsi]. Bandar Lampung: Universitas Lampung.

Wardoyo DY. 2008. Karakteristik Mikrobiologis Dendeng Sapi Giling dan Iris yang difermentasi dengan Lactobacillus plantarum 1B1. [Skripsi]. Bogor: Institut Pertanian Bogor.

Yuliani N. 2005. Komponen Asam Organik Tempoyak. Jurnal Teknologi dan Industri Pangan. vol 16 (1): 90-95.

Yulinery T, Nurhidayat N. 2015. Uji Aktivitas Antibakteri Lactobacillus plantarum Terseleksi dari Buah Markisa (Passiflora edulis) dan Kaitannya dengan 
Gen Plantarisin A (plnA). Prosiding Seminar Nasional Masyarakat Biodiversitas Indonesia. 20 Desember
2014. Depok: Masyarakat Biodiversitas Indonesia. ISSN 2407-8050. hal 270-277. 